\title{
Analisis Pengaruh Jumlah Nasabah, Tingkat Inflasi, dan Profit Pegadaian Syariah terhadap Jumlah Pembiayaan pada PT. Pegadaian (Persero) Cabang Syariah Kota Palembang
}

\author{
Muhammad Bahrul Ulum ${ }^{1}$ \\ ${ }^{1)}$ Program Studi Manajemen, Universitas Indo Global Mandiri \\ Jalan Jenderal Sudirman No 629 KM 4 Palembang Kode Pos : 30129 \\ Email : $\underline{\text { bahrulu1994@gmail.com }}$ (1)
}

\begin{abstract}
Financial institutions in Indonesia consist of two namely, bank financial institutions and non-bank financial institutions. In addition to functioning as an intermediary, the two institutions also have a function to channel funds to the public in the form of credit. One of the financial institutions that provide lending services to the public is PT. Pegadaian (Persero). PT. Pegadaian (Persero) develops business by opening sharia pawnshops because the majority of Indonesian people are Muslims, for example in the city of Palembang. Sharia pawnshops as a financing institution have a special purpose, namely lending money on the basis of mortgage law aimed at preventing the practice of bondage, dark pawnshops, usury, and other unnatural loans. The purpose of this study was to determine the effect of the number of customers, inflation rates, and profit of sharia pawnshops on the amount of financing at PT. Pegadaian (Persero) Palembang Syariah Branch. This study uses secondary data from the Central Statistics Agency and PT. Pegadaian (Persero) Palembang Sharia Branch in 2011-2014 and the analysis tool used is multiple regression analysis. In this study it was concluded that the profit of Islamic pawnshops had a positive and significant influence on the amount of financing at PT. Pegadaian (Persero) Syariah Branch of Palembang city, while the number of customers and the inflation rate does not significantly influence the amount of Financing at PT. Pegadaian (Persero) Palembang Syariah Branch.
\end{abstract}

Keywords : The number of customers, inflation rate, profit, and the number of financing

\begin{abstract}
ABSTRAK
Lembaga keuangan di Indonesia terdiri dari dua yaitu, lembaga keuangan bank dan lembaga keuangan non bank. Kedua lembaga ini selain memiliki fungsi sebagai lembaga intermediasi juga memiliki fungsi untuk menyalurkan dana kepada masyarakat dalam bentuk kredit. Salah satu lembaga keuangan yang memberikan layanan pemberian pinjaman kepada masyarakat adalah PT. Pegadaian (Persero). PT. Pegadaian (Persero) memngembangkan bisnis dengan membuka pegadaian syariah dikarenakan masyarakat Indonesia mayoritas beragama islam, contohnya di kota Palembang. Pegadaian syariah sebagai lembaga pembiayaan memiliki tujuan khusus yaitu penyaluran uang pinjaman atas dasar hukum gadai yang ditujukan untuk mencegah praktek ijon, pegadaian gelap, riba, serta pinjaman tidak wajar lainnya. Tujuan penelitian ini adalah untuk mengetahui pengaruh jumlah nasabah, tingkat inflasi, dan profit pegadaian syariah terhadap terhadap jumlah Pembiayaan pada PT. Pegadaian (Persero) Cabang Syariah kota Palembang. Penelitian ini menggunakan data sekunder dari Badan Pusat Statistik dan PT. Pegadaian (Persero) Cabang Syariah kota Palembang tahun 2011-2014 dan alat analisis yang digunakan adalah analisis regresi berganda. Dalam penelitian ini disimpulkan bahwa profit pegadaian syariah mempunyai pengaruh positif dan signifikan terhadap jumlah Pembiayaan pada PT. Pegadaian (Persero) Cabang Syariah kota Palembang, sedangkan jumlah nasabah dan tingkat inflasi tidak berpengaruh secara signifikan terhadap jumlah Pembiayaan pada PT. Pegadaian (Persero) Cabang Syariah kota Palembang.
\end{abstract}

Kata kunci : jumlah nasabah, tingkat inflasi, profit, dan jumlah pembiayaan 


\section{Pendahuluan}

Lembaga keuangan di Indonesia terdiri dari dua yaitu, lembaga keuangan bank dan lembaga keuangan non bank. Kedua lembaga ini selain memiliki fungsi sebagai lembaga intermediasi juga memiliki fungsi untuk menyalurkan dana kepada masyarakat dalam bentuk kredit. Lembaga keuangan bank maupun non bank selalu berusaha untuk memberikan pelayanan terbaik kepada masyarakat dalam bidang kredit (Kasmir, 2003).

Salah satu lembaga keuangan yang memberikan layanan pemberian pinjaman kepada masyarakat adalah PT. Pegadaian (Persero). PT. Pegadaian (Persero) adalah satu-satunya badan usaha di Indonesia yang secara resmi mempunyai izin untuk melaksanakan kegiatan lembaga keuangan berupa pembiayaan dalam bentuk penyaluran dana ke masyarakat atas dasar hukum gadai seperti yang dimaksud dalam Kitab Undang-undang Hukum Perdata Pasal 1150.

Bank sebagai lembaga keuangan belum dapat dijadikan alternatif pertama untuk memenuhi kebutuhan dana. Bank ternyata belum dapat bekerja semaksimal mungkin dalam menghimpun dan menyalurkan dana kepada masyarakat (Nuraini, 2008). Dalam kenyataannya hanya sebagaian masyarakat saja yang dapat menikmati jasa perbankan ini. Selain harus memiliki agunan atau barang jaminan, pemberian pinjaman di bank juga mensyaratkan prosedur pinjaman yang relatif lama dan sulit untuk dipenuhi bagi masyarakat yang memiliki ekonomi menengah kebawah (Wahyudi, 2008).

Keadaan tersebut menyebabkan banyak masyarakat yang membutuhkan dana cepat mengalihkan kebutuhan dananya ke pegadaian. Di pegadaian masyarakat dapat memperoleh dana yang dibutuhkan dengan waktu yang singkat dan biaya pemeliharaan barang juga masih terjangkau. Baik untuk kebutuhan konsumtif maupun untuk kebutuhan produktif (Nuraini, 2008).

PT. Pegadaian (Persero) sebagai lembaga pembiayaan yang memiliki tujuan khusus yaitu penyaluran uang pinjaman atas dasar hukum gadai yang ditujukan untuk mencegah praktek ijon, pegadaian gelap, serta pinjaman tidak wajar lainnya. PT. Pegadaian (Persero) meningkatkan peranannya dalam penyaluran pinjaman bagi masyarakat. Nasabah PT. Pegadaian (Persero) didominasi oleh masyarakat golongan ekonomi lemah yang kurang mendapat pelayanan dari lembaga keuangan atau perbankan sehingga masyarakat menengah kebawah memerlukan pinjaman secara mudah dan cepat. Kemudahan dan kesederhanaan dalam prosedur memperoleh pembiayaan merupakan modal dasar dalam mendekati pangsa pasar pegadaian (Wahyudi, 2008).

Permintaan pembiayaan dari masyarakat merupakan indikasi adanya kebutuhan dana bagi masyarakat untuk memenuhi kebutuhan hidupnya. Kondisi ketidakpastian ekonomi yang melanda Indonesia sejak beberapa tahun terakhir, inflasi yang senantiasa berfluktuasi dan lain sebagainya, diduga turut andil dalam jumlah kredit yang diminta oleh masyarakat (Purnomo, 2009).
Profit dapat diartikan sebagai ukuran keberhasilan perusahaan yang bersangkutan, apakah semakin maju atau berkembang, jika semakin menurun profitnya, maka cabang atau perusahaan tersebut tidak akan mencapai sasaran atau misinya (Wahyudi, 2008). Dalam hal ini, pegadaian berkesempatan mengambil peluang-peluang yang ada, guna meningkatkan jumlah profit. Upayaupaya yang dilakukan adalah menggarap potensi pangsa pasar baru dan menaikkan standar taksiran.

Gadai syariah pada dasarnya, sebagai bagian dari sistem keuangan yang merupakan tatanan dalam perekonomian suatu Negara yang memiliki peran, terutama dalam menyediakan jasa-jasa dibidang keuangan. Karena gadai syariah bagian dari lembaga keuangan non perbankan yang dalam usahanya tidak diperkenankan menghimpun dana secara langsung dari masyarakat dalam bentuk simpanan, maka gadai syariah hanya diberikan wewenang untuk memberikan pinjaman kepada masyarakat (Sasli, 2006).

Produk - produk berbasis syariah memiliki karakteristik seperti, tidak memungut bunga dalam berbagai bentuk karena riba, menetapkan uang sebagai alat tukar bukan sebagai komoditas yang diperdagangkan dan melakukan bisnis untuk memperoleh jasa dengan sistem bagi hasil. Pegadaian syariah atau dikenal dengan istilah rahn, dalam pengoperasiannya Mudharabah (bagi hasil). Terbitnya PP/10 tanggal 1 April 1990 dapat dikatakan menjadi awal berdirinya Pegadaian, satu hal yang perlu dicermati bahwa PP10 menegaskan misi yang harus diemban oleh Pegadaian untuk mencegah praktik riba, misi ini tidak berubah hingga terbitnya PP103/2000 yang dijadikan sebagai landasan kegiatan usaha PT. Pegadaian (Persero) sampai sekarang. Banyak pihak berpendapat bahwa operasionalisasi Pegadaian pra Fatwa MUI tanggal 16 Desember 2003 tentang Bunga Bank, telah sesuai dengan konsep syariah meskipun harus diakui belakangan bahwa terdapat beberapa aspek yang menepis anggapan itu. Berkat Rahmat Allah SWT dan setelah melalui kajian panjang, akhirnya disusunlah suatu konsep pendirian unit Layanan Gadai Syariah sebagai langkah awal pembentukan divisi khusus yang menangani kegiatan usaha syariah. Konsep Pegadaian Syariah juga mengacu kepada syariah Islam yang bersumber dari Al-Quran dan Hadist Nabi SAW. Adapun landasan yang dipakai adalah Qur'an Surat Al Baqarah ayat 283 yang artinya:

"Jika kamu dalam perjalanan (dan bermu'amalah tidak secara tunai) sedang kamu tidak memperoleh seorang penulis, maka hendaklah ada barang tanggungan yang dipegang (oleh yang berpiutang). Akan tetapi jika sebagian kamu mempercayai sebagian yang lain, maka hendaklah yang dipercayai itu menunaikan amanatnya (hutangnya) dan hendaklah ia bertakwa kepada Allah Tuhannya dan janganlah kamu (para saksi) menyembunyikan persaksian. Dan barangsiapa yang menyembunyikannya, maka sesungguhnya ia adalah orang yang berdosa hatinya dan Allah Maha Mengetahui apa yang kamu kerjakan."

Pegadaian Syariah kota Palembang merupakan salah satu lembaga keuangan di kota Palembang yang 
memiliki beberapa kantor cabang. Dengan selalu berinovasi menyediakan kebutuhan akan finansial pegadaian syariah yang menyesuaikan dengan kebutuhan akan dana, pembiayaan serta kepemilikan kendaraan dan emas batangan kepada masyarakat.

Penelitian mengenai pegadaian syariah masih sangat sedikit dilakukan. Hal ini tentunya akan lain di masa mendatang, dimana para peneliti akan lebih tertarik untuk meneliti industri pegadaian syariah apabila peraturan perundang-undang yang berlaku telah memungkinkan swasta maupun badan usaha milik pemerintah lainnya masuk dalam bisnis pegadaian syariah.

\section{Pembahasan}

\section{A. Kerangka Pemikiran Teoritis dan Perumusan Hipotesis}

Penelitian ini mengenai analisis pengaruh jumah nasabah, tingkat inflasi, dan profit pegadaian syariah terhadap jumlah pembiayaan. Dimana hasil penelitian terdahulu masih terdapat perbedaan. Adapun kerangka pemikiran teoritis penelitian ini dapat kita lihat sebagai berikut:

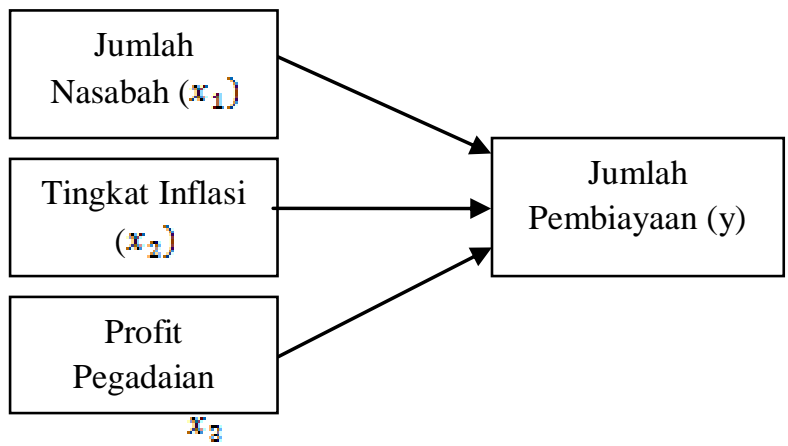

Hipotesis:

Jumlah nasabah, tingkat inflasi, dan profit pegadaian syariah berpengaruh signifikan terhadap jumlah pembiayaan pada PT. Pegadaian (Persero) cabang syariah kota Palembang

\section{B. Metode Penelitian}

Penelitian ini membahas tentang pengaruh jumlah nasabah, tingkat inflasi, dan profit pegadaian syariah terhadap jumlah pembiayaan. Objek yang diteliti adalah PT. Pegadaian (Persero) Cabang Syariah kota Palembang. Data yang digunakan memiliki rentang waktu dari Januari 2011 hingga Desember 2014. Dalam penelitian ini menggunakan data kuantitatif, yaitu data yang berupa angka, dapat dianalisis dengan menggunakan teknik perhitungan statistik. Data bersumber dari hasil laporan Badan Pusat Statistik kota Palembang dan PT. Pegadaian (Persero) Cabang Syariah kota Palembang.

Setelah data diperoleh selanjutnya dilakukan analisis data dengan menggunakan software komputer Eviews 7. Model analisis yang digunakan adalah analisis regresi linier berganda yang bertujuan untuk mengetahui koefisien determinasi, koefisien regresi, pengaruh parsial dan pengaruh simultan variabel bebas terhadap variabel terikat melalui pengujian hipotesis secara parsial menggunakan $\mathrm{t}$ test dan pengujian hipotesis secara simultan menggunakan $\mathrm{F}$ test. Model persamaan linier yang menyatakan hubungan variabel bebas dan terikat adalah sebagai berikut:

$\operatorname{LnY}=\alpha+\beta 1 \operatorname{Ln} x_{1}+\beta 2 x_{2}+\beta 3 \operatorname{Ln} x_{3}+e$

Selanjutnya dilakukan uji asumsi klasik agar persamaan yang dihasilkan bersifat BLUE (Best Linier Unbiased Estimator), yaitu:

1. Uji multikolinieritas bertujuan untuk menguji dalam model regresi yang terbentuk ada korelasi yang tinggi atau sempurna diantara variabel-variabel bebas atau tidak.

2. Uji heterokedastisitas dilakukan untuk menguji dalam model regresi terjadi ketidaksamaan deviasi standar nilai variabel terikat pada setiap variabel bebas atau tidak.

3. Uji otokorelasi bertujuan untuk mengetahui apakah ada korelasi antara anggota serangkaian data observasi yang diuraikan menurut waktu (timesseries) atau ruang (cross section) (Suliyanto, 2011).

Jika terjadi penyimpangan terhadap asumsi klasik maka persamaan regresi linier yang dihasilkan tidak dapat dipergunakan untuk memprediksi jumlah pembiayaan dan hasil uji $\mathrm{t}$ dan uji $\mathrm{F}$ dinyatakan tidak valid.

Hasil estimasi menyatakan bahwa bebas dari masalah normalitas, multikolinieritas, lulus uji heterokedastisitas dan tidak ada masalah otokorelasi, maka dari hasil hasil uji t. Hasil uji F, serta uji regresi linier berganda dengan menggunakan program computer Eviews 8diperoleh hasil estimasi persamaan regresi linier berganda sebagai berikut:

$R^{2}$ dalam regresi sebesar 0.716756 . Ini berarti variabel jumlah pembiayaan (Y) dapat dijelaskan oleh variabel jumlah nasabah $\left(x_{1}\right)$, tingkat inflasi $\left(x_{2}\right)$, dan profit pegadaian syariah $\left(x_{3}\right)$ sebesar 71,67 persen, sisanya dijelaskan oleh variabel lain di luar model.

Hasil uji $F$ menunjukan bahwa Nilai prob. F (Statistic) sebesar 0,000000 lebih kecil dari tingkat signifikansi 0,05 sehingga dapat disimpulkan bahwa model regresi yang diestimasi layak digunakan untuk menjelaskan pengaruh jumlah nasabah, tingkat inflasi, dan profit pegadaian syariah terhadap jumlah pembiayaan.

Nilai prob. t hitung dari jumlah nasabah sebesar 0.2069 yang lebih besar dari 0,05 sehingga jumlah nasabah berpengaruh namun tidak signifikan terhadap jumlah pembiayaan. Sama halnya dengan pengaruh inflasi terhadap jumlah pembiayaan, karena nilai prob. $\mathrm{t}$ hitung (0.2220) yang lebih besar dari 0,05 sehingga dapat dikatakan bahwa inflasi berpengaruh namun tidak signifikan terhadap jumlah pembiayaan. Perbedaan terjadi pada variabel profit pegadaian syariah. Nilai prob. $\mathrm{t}$ hitung dari variabel profit pegadaian syariah sebesar 0,0000 yang lebih kecil dari 0,05 sehingga variabel bebas profit pegadaian syariah berpengaruh 
signifikan terhadap jumlah pembiayaan pada alpha 5\% atau dengan kata lain, profit pegadaian syariah Jadi berpengaruh signifikan terhadap jumlah pembiayaan pada taraf keyakinan $95 \%$.

\section{Kesimpulan dan Saran}

Berdasarkan hasil penelitian mengenai analisis pengaruh jumah nasabah, tingkat inflasi, dan profit pegadaian syariah terhadap jumlah pembiayaan pada PT. Pegadaian (Persero) Cabang Syariah kota Palembang yang parameternya menggunakan metode OLS telah mengungkapkan pengaruh dari jumah nasabah, tingkat inflasi, dan profit pegadaian syariah, maka dibuat kesimpulan sebagai berikut:

1. Jumah nasabah, tingkat inflasi, dan profit pegadaian syariah secara keseluruhan mempengaruhi jumlah pembiayaan pada PT. Pegadaian (Persero) Cabang Syariah kota Palembang, hal ini terlihat dari pengujian serentak yang telah dilakukan.

2. Jumah nasabah, tingkat inflasi, dan profit pegadaian syariah mampu menjelaskan proporsi pengaruh variasi total dari jumlah pembiayaan pada PT. Pegadaian (Persero) Cabang Syariah kota Palembang yang dicerminkan dalam penghitungan koefisien determinasi $(\mathrm{R})$ dalam model statistik.

3. Hasil pengujian secara individual menunjukkan bahwa variabel Jumlah nasabah berpengaruh secara positif namun tidak signifikan terhadap jumlah pembiayaan pada PT. Pegadaian (Persero) Cabang Syariah kota Palembang.

4. Hasil pengujian secara individual menunjukkan bahwa variabel inflasi berpengaruh secara positif dan tidak signifikan terhadap jumlah pembiayaan pada PT. Pegadaian (Persero) Cabang Syariah kota Palembang.

5. Hasil pengujian secara individual menunjukkan bahwa variabel profit pegadaian syariah berpengaruh secara positif dan signifikan terhadap jumlah pembiayaan pada PT. Pegadaian (Persero) Cabang Syariah kota Palembang.

Berdasarkan kesimpulan yang dikemukakan di atas, saran berkaitan dengan hasil penelitian adalah :

Berdasarkan hasil yang diperoleh dalam penelitian ini,bahwa jumlah pembiayaan yang disalurkan oleh PT. Pegadaian (Persero) Cabang Syariah kota Palembang dipengaruhi oleh indikator-indikator eksternal maupun internal seperti jumlah nasabah, tingkat inflasi dan profit pegadaian syariah maka diperlukan langkah-langkah untuk lebih meningkatkan perhatiannya terhadap ketiga komponen tersebut, dengan harapan semakin stabilnya kondisi Pegadaian syariah dan meningkatkan kembali peran Pegadaian untuk mengatasi masalah masyarakat dalam upaya menyelaraskan pembangunan dan pertumbuhan ekonomi di Indonesia teruatama di kota Palembang.

\section{Daftar Pustaka}

Al-Qur'an dan Terjemahannya, 2013, Departemen Agama RI. Jakarta: Assobar Qur'an. Kasmir, 2003, Bank dan Lembaga Keuangan Lainnya, 6th Ed. Jakarta: PT. Raja GrafindoPersada.

Nuraini, Yustiana Ratna, 2008, Analisis Faktor-Faktor Yang Mempengaruhi Permintaan Kredit Perum Pegadaian Bogor. Skripsi pada Departemen Ilmu Ekonomi Fakultas Ekonomi Dan Manajemen Institut Pertanian Bogor (tidak dipublikasikan).

Peraturan Pemerintah Indonesia Nomor 10, tahun 1989 tentang Pegadaian. 1990. Jakarta.

Purnomo, Ade, 2009, Pengaruh Pendapatan Pegadaian, Jumlah Nasabah, dan Tingkat Inflasi terhadap Penyaluran Kredit pada Perum Pegadaian Syariah Cabang Dewi Sartika Periode 2004 - 2008. Skripsi pada Program S-1 Ilmu Ekonomi Universitas Gunadarma (tidak dipublikasikan).

Sasli, 2006, Pegadaian Syariah: Konsep dan Sistem Operasional, Jakarta: UI Press.

Suliyanto, 2011, Ekonometrika Terapan: Teori \& Aplikasi dengan SPSS. Yogyakarta: Penerbit Andi.

Wahyudi, Amen, 2008, Analisis Penyaluran Kredit Perum Pegadaian Di Propinsi Daerah Istimewa Yogyakarta. Skripsi pada Universitas Islam Indonesia (tidak dipublik asikan). 